\title{
Incorporation and Resistance: Border-Crossings and Social Transformation in Southeast Asia (Review Article)
}

\author{
Alexander Horstmann ${ }^{1}$
}

\section{New Horizons in Southeast Asian Studies}

While permeable and ambiguous national borders can be said to play a crucial role in Anderson s work (1983) on the imagined community of the modern nation as well as in Thongchai s path-breaking study (1994) on the emergence of a hierarchical ethno-geography of modern Siam, it is astonishing how little attention has been given so far to international borders in Southeast Asia.

There are strong reasons why the study of borders is timely. The borderland can be conceptualized as a laboratory of social change in Southeast Asia. There is no place in the nationstate where the contradictions of representation of bounded collectivities could be clearer. In fact, the very nature of international borders has produced and invented ethnic minorities which have been submitted into marginal positions on the frontier of the nation-sate. Thongchai Winichakul (2000) shows that the formation of the territorial Thai geo-body implies from the very beginning a hierarchical relationship of the national centre and the other not only in terms of class and status, but in terms of a ethno-geography as well. It can be said that peripheral ethnicity has been produced in Foucauldian regimes of power and truth which define their place in the national community. To be sure, many scholars have written ethnographies on the transformation of livelihoods of ethnic minorities on the borders. Yet, as Tapp (2000) remarks not without selfcriticism, scholars of ethnic minorities tend to essentialise the identities of their ethnic minorities and tend to underplay the relationships with powerful ethnic majorities.

Anthropologists and geographers have increasingly challenged the way in which we view the political organization of the state and the compartmentalization of the world. Newman and Paasi (1998) argue that boundaries and their meanings are historically contingent, and they are part of the production and institutionalization of territories. In this sense, all boundaries are socially constructed. Attention should be paid to boundary-producing practices and to narratives of inclusion and exclusion. These ideas about boundaries and territoriality are particularly important in the contemporary world where social groups aim to define and redefine the relations between social and physical space.

The people on the fringe of the nation-state are questioning the monopoly of identification and help to transform taken for granted concepts of nationalism. Their practices of crossing international borders in a routine fashion have important implications for our understanding of spatial and social organization of society and culture. In this way, the everyday life of frontier communities is shaking some of the basic assumptions in social anthropology which are unconsciously bound to a spatial system which is characterized by more or less exclusive boundaries of the nation-state.

In particular, the focus on the intensification of border crossing practice overcomes the straightjacket of the nation-state. We have to be conscious of the fact that ethnic minorities are split in different nation-states by international borders. In this essay, studies of border-crossings are compiled and put into a comparative scheme. We aim to decipher common research 
questions and emerging paradigms on which a middle-range theoretical concept can be built which might justify the field of anthropology of borders in Southeast Asia. ${ }^{2}$

The objectives of this review article are threefold. The study of border crossing practices in Southeast Asia is a very recent field. Thus, a short introduction will help to situate border studies in Southeast Asia into larger debates on ethnicity, nation-state and the politics of identification. Although the second part is descriptive and empirical in nature, we envisage a comparative scheme which allows us to identify common research categories, leading to a more systematic approach to what are individual and scattered studies in Southeast Asia. Thirdly, an agenda and its implications for social and cultural change in Southeast Asia is proposed. We suggest that in the light of border crossings static concepts of nation-state, culture and society may be seen in a new light.

\section{Frontiers of Nation and State}

The thesis which is presented here is that borderlands in Southeast Asia are laboratories of social and cultural change. Borderlands represent the state margin and magnify ethnic relations in Southeast Asian countries and the explosion of identity politics.

As Newman and Paasi (1998) argue in their persuasive survey of boundary narratives in political geography, boundaries and borders were initially conceived as being no more than lines separating sovereign territories, while frontiers were assumed to constitute the area in proximity to the border whose internal development was affected by the existence of this line. In the context of Southeast Asia, anthropologists have until the $90 \mathrm{~s}$ turned a blind eye to state borders.

Rajah discusses definitions of the state, inventioned identity and imagined community in relation to national boundaries in mainland Southeast Asia. He argues that pre-colonial and postcolonial states may co-exist at the Thai-Burmese border and that the Karen separatists, in controlling the means of ethnic identification (the schools), form their own imagined pre-colonial state along the Burmese frontier. On the basis of his empirical material, Rajah $(1990,122)$ argues that

There are clearly some important issues in the study of ethnic group formation (ethnogenesis) across national boundaries, and the state, which are obscured by the fact that we, as Wijeyewardene (1989) has cautioned, tend to think in post-nation state terms.

Rajah sets out to develop a framework in which anthropologists pay more attention than hitherto to the relationship between ethnic boundaries, national boundaries, and the state. He points out that what is at stake is the capacity of the state to control and maintain its boundaries and what is contained within these national boundaries. Thus, in Rajah s opinion, it is more appropriate to say that there is a Thai border and a Burmese-Karen frontier region, and that the Karen separatist movement- and even the Burmese state- may be viewed as a kind of traditional state.

The unquestioned and unquestionable nature of the nation-state has come to dominate so much contemporary thinking and social science discourse (see Benjamin 1988). Rajah raises fundamental questions on the use of colonial knowledge in social science discourse. Western anthropological discourse (and, indeed, the discourse of the state) on ethnic minorities as primitive, tribal or stateless should be abandoned. Moving the frontier to the centre stage, the state can be liberated from its mystical or quasi-sacred character and, in a post-colonial 
perspective, be deconstructed in its various parts. The Karen nationalist movement in (postnational) Burma may be seen as a form of political organization, which controls the hilly area along the border (territory), the illegal border trade (economy) and the means of identification (education) with the Karen nation-state (military headquarters). The Karen movement in Burma is operating from the Thai-Burmese border because of the border, which offers retreat for bases and refugees. Rajah writes: \&the notion of a border between existing states is intrinsic to the application of ideas about a common culture, language, and social and political organization, and their associated discontinuities. The incapacity of the modern state to maintain its boundaries make an excellent case to question the bases of the ideological baggage on which the modern nation-state is based: land, population and the means of identification. ${ }^{3}$

\section{Active Borderlands}

We like to reinforce a perspective which chooses social agency in the Southeast Asian borderlands as main focus of research. The emphasis on border crossings lies in a new quality and intensification of border crossing networks and spaces which transcends political boundaries.

As Donnan and Wilson (1999) point out, borders are not just symbols and locations of these changes, but are often also their agents. It is not surprising that the concept of transnationalism, which has become so central to interpretations of global society, has international borders as one of its principal referents. However, relatively little attention has been paid to the negotiation of border-crossing agents and the physical power of the state on the physical ground of borderlands. The concept of transnational social spaces has shown that the durable and regular networks of international migrants result in the transnationalisation of time and space (Pries 2000). In this discourse, the nation-state seems to impinge less and less on the lives of international migrants. This perspective is belied by the fact that migrants are subjected to tighter immigration laws and suppression which pushes a great number of migrants into illegal status and excludes them from basic human rights and participation. This essay argues that the negotiation of populations and state is particular intense in the borderlands of Southeast Asia and that this interaction should be the focus of research. For not only are the borderlands symbols and locations of social and cultural change in Southeast Asia, they are often their agents as well.

Border-crossing populations are lying at the edge of current transformations of concepts of sovereignty, national identity and citizenship. While many studies seem to propagate this trend, only few studies are grounded on solid empirical fieldwork. Many studies on ethnic minorities in Southeast Asia do not take the border and its conceptual impact into full account. In the same line of argument, most studies limit themselves to one country and largely ignore the practice of border-crossing and the transnationalisation of social space which involves two or more countries and may, through multiple networks and cultural contact over wide geographical distances, extend to pluri-local spaces, sometimes spanning continents.

It is crucial that there are two sorts of narratives of the borders, that by the state and that by the populations which inhabit the borders. The anthropology of borders is interested in the narrative of borderlanders. As Baud and Van Schendel (1997) indicate in their review of the history of borderlands, while much has been written on how states deal with their borderland, historians have paid much less attention to how borderlands have dealt with their states.

We follow Baud and van Schendel in eschewing center sights in favor of a new view from the borders and their populations themselves (Baud and van Schendel 1997: 212): 
Such efforts seek to redress the imbalance of state-cantered studies, and to discover which social forces originate in borderlands along with the effects they have had both locally and beyond the borderlands. Borderlands in recent historical scholarship are placed at the centre of study, and a focus on them is seen as a productive way to generate meaningful comparisons with other borders and states, in an effort to develop equivalent descriptive categories and workable theories.

Thus, Baud and van Schendel suggest that borderlands should be seen as social and cultural systems which transcend the state boundary and which have been active in the construction of their states, and have not just been passive dopes. Borderlands should be placed in their spatial and temporal contexts in order to investigate the relations between territory, identity and sovereignty.

The impact of a particular world historical transformation (world time) on social change in borderlands must be related to the developmental phases of the states concerned (state time), as well as the stages of the life cycle in which individual borderlands find themselves (borderland time).

While the supposed unity of community and nationhood assumes shared bonds, a shared time and space, those assumptions, supported by law as well as by convention, are out of touch with the lack of unity, the multiple disjunctions, the separate spaces and times which structure experience in border-crossing networks and grassroots movements (Shapiro 1996). The communication technologies overwhelm the stable time and space to which nation-centred citizenship has been attached, while the lives of border communities escape from the unities of national solidarity and are increasingly attached to global culture.

\section{Reproduction and Myth of Nationalism}

The hegemonic national cultures of the post-colonial state in Southeast Asia have been a nightmare for ethnic minorities who have been marginalized or folklorised in the space of the nation-state and constructed as inferior races. Far from fading away, the border is a central place, in which land, population and identification is most contested. In favour of defining borders, Donnan/Wilson (1999) argue that with border concepts in danger of being everywhere, efforts should be more focused in favour of state borders. This approach is concerned with the study of power in and between nation and states at the local level of borders. The border plays a special role in the origin and development of states precisely because of their geographical location which sets border zones apart from the more homogenous, developed and powerful zones in the centre. Borders are markers of statehood. They are the political membranes through which people, goods, wealth, and information must pass in order to be deemed acceptable or unacceptable by the state.

As argued in the beginning of this essay, frontiers are complex social systems which question the nature of the state. In Southeast Asia, maybe with the exception of Singapore, the sovereignty of the state in the border region is marginal and sometimes even abandoned. In fact, the cultural border is not definitive, and cultural boundaries between communities reach much further into the geo-body of the nation or beyond the territorial limitation of the nation.

The special character of cultures at borders at the local level is an idea to be kept. In Southeast Asia, the most vulnerable local minorities are found in border regions. The politics of homogenization are played out in the remote corners of the country in relation to language, 
religion and way of life. Border regions have developed a highly specific culture with things as they are because of the border. Thus, in the context of economic expansion, border towns are booming and rapidly growing. In addition to the local fare, one finds the goods of the border trade, e.g. gems, drugs and teak from Burma, consumer items from Thailand. Huge sums of money are created in the illegal trade at the borders and social forces, e.g. the Thai military, are making use of the border and its political ecology. The economic sectors of border regions, e.g. fishery, and plantations, greatly depend on migrant labour from neighbouring countries. In summary, the political and cultural landscape of the border region should be underlined. Donnan and Wilson conceptualize borders in relation to the nation, including the ways in which borders are enhanced or diminish. In this essay, we propose that border communities have their own local perception of the border and that in the beginning of the 21 . Century, the borderland is not limited to the state borderline, but encompasses spaces in the centre. Thus, migrants who arrive in Ranong, a province on the Southern end of the Thai-Burmese border, continue to look for jobs in Songkla and Bangkok and in Malaysia, extending the borderland to the centre. Linguistic, cultural and religious networks extend widely beyond the territoriality of the nation-state and put nationalism under great pressure. Instead of assuming a definitive nature of border landscape in Southeast Asia, the empirical assumption which is underlying our research is the ambiguity of the border.

Many borders exist only on the map. Fieldworkers told me that traders in Borneo have upset the authorities by dismantling the border markers, thereby underlining the fuzziness and ambiguity of the end of the nation. Border identities in Southern Thailand enter a post-colonial stage in which the boundaries between Thai and Malay identity become increasingly blurred. In this place, where identity and culture is fuzzy and shifting, national intimacy is being negotiated by the local powers and social forces in the border region. It is argued that in this negotiation of borders, national intimacy can be reinforced or fragmented. In a post-national world, bordercrossing affects the everyday life of border people who are shuttling between two or more countries. In a global age, border-crossing movement in travel, pilgrimage and manifold networks results in numerous encounters and affiliations, which can not be grasped in the framework of the nation-state. Even in Singapore, although trying hard, the state is not able to control ethnic and religious networks on a global level. That does not mean that national identity becomes meaningless. Horstmann (forthcoming) shows that transnational Buddhist networks and pilgrimage route which link Had Yai with Kedah are reviving blood ties between the Thai heartland and the Thai Diaspora in Malaysia, thereby strengthening Thai nationalism in daily practice. On the other hand, in the proliferation of durable and regular transnational social spaces with Malaysia, Indonesia and the Middle East, Pattani Muslims are creating their own moral communities, effectively criss-crossing the political and cultural boundaries of the nation. The argument forwarded is that a reduction of the analysis of borders to nation and state-borders is in danger to overlook the fact that apart from the state there are other worlds of reference. In his the peasant robbers of Kedah 1900-1929, Cheah Boon Kheng (1988) shows that rural crime in Kedah, while of much concern to the colonial state, operated largely outside of it. Many of the most notorious gang leaders were so-called Sam-Sam (meaning half-blood), Thai-speaking Muslims who were playing and making use of on the ambiguity of their identity between the Thai and the Malay world. Clearly, the colonial and post-colonial state, mistrusting the loyalty of ethnic minorities on the edge of the state, has been involved in gigantic operations of development and sometimes state terrorism in order to transform uncertain borderlands into 
national landscapes. Most of these state projects failed. Following Herzfeld (1997), scholars of borderlands might be interested to explore just how notions of new national emotions are constructed in the growing encounters with the alien worlds which increasingly intrude upon hegemonic landscapes. Embracing Thongchai s marginal history project (Thongchai Winichakul 2002), we argue that the historical study of borderlands is particularly well suited to study the formation of the nation from the borders. ${ }^{4}$

\section{The Project of Marginal History}

The study of borderlands gives new impetus to the margin. In the same line, a focus on the everyday life and struggle of borderlanders gives impetus to forgotten or suppressed histories of the local. In a recent paper (2002), Thongchai Winichakul has called for the project on marginal history from the interstices in Southeast Asia. The study from the margin has a huge potential to tell stories from a particular location: The end of the nation-state and the beginning of an autonomous history. At those interstices, it is possible to discern the discursive regime of a national history, its logics, conditions, constitutions, mechanism, and reproduction: This is what I call history at the interstices, that is, the history of the locations and moments between being and not being a nation, becoming and not becoming a nation (Thongchai Winichakul 2002, p.5). Marginal history is a local history of national minorities which have been forgotten or suppressed by national history. From a spatial perspective, the marginal history is an extremity where the nation-state ends. The marginal is politically, economically and culturally peripheral and subdued to the centre. Thongchai is using the definition of the marginal by anthropologist Anna Tsing:

Margins are conceptual sites from which to explore the imaginative quality and the specificity of local/global cultural formation. Margins here are not geographical, descriptive locations. Instead, I use the term to indicate an analytic placement that makes evident both the constraining, oppressive quality of cultural exclusion, and the creative potential of rearticulating, enlivening, and rearranging the very social categories that peripherise a group s existence.

But whose history is to be retold? Thongchai s text is a plea for the rediscovering of local stories and the interaction of the local with the global and the processes of local globalization by which global sweeps are being localised and changed. Obviously, this project needs a new approach to the writing of history. In Siam mapped Thongchai Winichakul (1994) himself has followed the path of the centre and the elitist view in order to deconstruct the myth of the nation-state. This work has already pointed to the ambiguity of the margin which has been harnessed by the technologies of administration, infrastructure and mapping. But does not the writing of history from the interstices require the rethinking of methodology as well? The local stories of post-national history require a particular sensibility for the everyday-life and for the resistance to efforts of state-building, simplification and normalisation. Oral history seems to be a very apt methodology with which the colonial documents of the state can be compared. Confronting oral and colonial histories of rebellion and pacification (genocide), Wadley (2002) suggests that colonial and Iban narratives provide conflicting accounts of the events. The expedition in which Brooke forces were struck with a cholera epidemic is remembered as divine revenge of the spirits which turned against their enemies who sought to strike against them again and which re-established the moral order of tribal society. 


\section{Social and Spatial Organisation of Ethnic Minorities}

Tapp (1989) argues that the border has greatly affected the lives of ethnic minorities who find themselves on one side or the other of it. He argues that the reality of the frontier has led to the increasing vulnerability of marginal ethnic minorities in the border areas to the manipulation and exploitation by centrist administrations. Tapp draws attention to the discourse on the state which classifies much of human movement and trade as illicit. Trade is classified as smuggling and human mobility is categorized as illegal immigrant and refugee.

However, Horstmann $(2001,2002)$ argues that the politics of citizenship produces certain categories of people, citizen and non-citizen. In the same light, ethnic minorities are constructed peripheral identities which are trapped in the space of the nation-state. They are trapped in the sense that they are cut from well-established and meaningful kin and trade relations. Moreover, as they become assimilated into an alien majority, they become suspicious to the Diaspora. The border is the most important symbol of statehood. The border subjects ethnic minorities in marginal spaces to levels of incorporation. Southeast Asia knows manifold stories of state formation and expansion, nationalism and cultural imperialism. The study of borderlands is concerned with various geographies of incorporation. Local, national and international levels merge and intersect at the frontier.

As Bryant explains, the history of the Karen is intimately linked to the use of natural resources (Bryant 1997). ${ }^{5}$ In order to understand the link between Karen forestry and sovereignty, the history of Karen forest use needs to be reviewed. The construction of Karen ethnicity has been linked to the policies of colonial officials and missionaries. Under British rule, the idea of a Karen nation developed through a separate language, education system and culture. The Karen represent an exemplary border community, trapped as they are on the Thai-Burmese border. The Karen found themselves under the jurisdiction of states over which they had no control. Forests use and management was inevitably an important part of their life and identity. The Karen were prominent in the extraction and marketing of teak which the British sought much after for the construction of ships. Later, these links became an integral part of the struggle of the Karen with the Burmese army. The forests have served as a source of refuge from the Burmese army. Under the Four Cuts counter-insurgency campaign, local Karen were forcibly removed from their villages and resettled in army-controlled settlements. The civil war has resulted in the displacement of thousands of Karen who are living in Thai refugee camps on the border or who are being displaced within Burma on refuge from horrible human rights violations of Karen civilians. ${ }^{6}$ An illicit border trade in natural resources, especially teak, and consumer goods, on which the Karen imposed a 5 per cent tax, provided crucial revenues for the Kawthoolei Karen state and the KNU Karen army. The main task of the forestry ministry of the Kawthoolei state was to monitor teak extraction. Heavy forest depletion resulted from the SLORC s decision to grant logging concessions to Thai firms supported by the Thai military and the desperate overcutting permitted by the KNU to maintain forest-based earnings and to sustain the war. The teak war resulted in the rapid destruction of Karen forests as the Thai loggers took advantage from the political conflict. Bryant argues that the SLORC-engineered assault on the border forests simultaneously attacked Karen identity in which the forest figured prominently. In front of the military assault of the Burmese army which captured the Karen National Union $s$ headquarters in Mannerplaw in January 1995, the Karen sanctioned the depletion of its forests which provided their main means of livelihood. 


\section{Indigenous Resistance to the Colonial and Post-colonial State}

Colonial interests shifted from maintaining favourable trade zones along the coasts and rivers to an increasing control of territory and its human populations. Many territorial boundaries were established as a result of competition between European colonial powers and their grip on people, resources and territory. Wadley (2001) shows that the Iban in the West Borneo borderlands frustrated much of the efforts of the Brooke regime and the Dutch colonial state in defining and demarcating state borders. The Iban defied both colonial powers in refusing to end their headhunting practices, pay imposed taxes or seek permission to move across the border. From the colonial perspective, boundaries were designed to restrict trade and movement of people across the inter-colonial border and to promote activities like taxation, road construction and resource extraction. The efforts to extend the colonial influence over the border Iban culminated in numerous punitive expeditions on the Iban living on both sides of the border which laid Iban longhouses in waste and killed many people, including women and children.

Wadley (2000a, 2001, 2002) and Ishikawa (2001) make use of colonial archives to highlight the interaction of local people and colonial powers. The formation of the border is a crucial part of the ambition of the colonial state to establish control over people and territory in the occupied land and to force them to produce revenues for the colonial masters. However, the local perception of the border differs from the vision of the colonial state. The Iban made (and make) regular use of the border to evade taxes, to escape from punishment from one state or the other and from forced conscription, and for headhunting. Evasion and flight were among the most sufficient strategies of everyday resistance which the Iban used to counter colonial claims over their lives. Likewise, Ishikawa focuses on the border controls and other disciplinary mechanisms which aimed to incorporate local people in south-western Sarawak, adjacent to Dutch Borneo into nation-state space. The Brooke regime sought to control movements of mobile people across the border. Further, the government sought to define the national affiliation of colonial subjects through naturalization and marriage regulation. Local people frustrated the ambitions of the Brooke regime by smuggling, migration, transnational bigamy and strategic naturalization. Perhaps it is possible to go even further: As the manifold disciplinary mechanisms have been defied by local people, the colonial regime existed on paper rather than in local reality. The colonial powers did not have the means to enforce their borders in time and in space. Once they left, the Iban would have no reason to keep the difficult promises to their colonial lord.

\section{Border Crossing and Migration}

Migration has played a decisive role in the making of society and culture in Southeast Asia. In the reign of the passport, island hopping among seafaring communities becomes illicit movement and the politics of citizenship and identity come to full circle. Boat nomadism is everywhere disappearing from maritime Southeast Asia. Sather (1997) reports that boat nomadism has taken on a new meaning in the present for the Sama refugees from the Sibutu and Tawittawi island groups of the Southern Philippines and the dispossessed of Sulu. Most have returned to their boats in order to escape civil war, violence, declining fish stocks and the destruction of coral. Miyazaki (2000a) puts it very aptly, when he writes that people who have habitually moved as part of their life worlds are now settling, while hitherto sedentary people have begun to move. Migration arrests our attention, because it puts the border into question and challenges the nature of a seemingly established system, e.g. the nation. In a world-system perspective, frontiers are zones of demarcation and contact between groups in the making of more centralised systems and 
states. Migrants played a decisive role in the construction of the communities, systems and states and their boundaries.

Janet Carsten (1997) found that the village of Sungai Cantik in Langkawi is a village founded and made up by migrants. Although people in the village are engaged in the practice of forgetting and deemphasising cultural difference, Carsten $s$ data suggest that many grandparents came from outside Langkawi, with localities of origin including Pinang, Kedah, Perlis, southern Thailand, Aceh, Minangkabau, and Java. Acehnese ancestors may have well been among the founding members of the village. Carsten notes that the villagers ignored as far as possible the bureaucratic implications of moving across a modern international frontier and regarded Southern Thailand as much of their social world. In my own fieldwork, a troupe of musicians and artists from Langkawi came with their Thai Muslim wives and their children and was accompanied with considerable enjoyment about the trip without using any visa. In the same region, Horstmann (2001) is interested in the social networks which are emerging in the context of intensified border crossings at the Thai-Malaysian border. One of his most significant findings was that ethnic minorities in the borderland are reworking centrist state concepts to their personal advantage. Horstmann argues that the local reworking of citizenship is part of struggle in which the state sets important constraints on human movement. The state is issuing border passes to the inhabitants of the border provinces in order to control the movement of people. Muslim people in Southern Thailand are making use of kinship relations and religious networks to get citizenship rights in Malaysia. Multiple citizenships and the organization of everyday life, work, and Islamic education in Thailand and Malaysia is a response to the tightening immigration regime in Malaysia and the restrictions implemented by the Thai and Malaysian governments.

The local resistance to restrictions implemented by the colonial Brooke regimes is detailed by Ishikawa (2001). The Brooke regimes introduced various methods to control cross-border movements of mobile people from Dutch Borneo to Sawarak- among them indentured Chinese labourers, maritime Malay migrants Dayak swidden cultivators. Further, the government sought to define the national affiliation of colonial subjects through naturalization and marriage regulations. Among the response of local people was resistance in the form of commodity smuggling, cross-border movement, transnational bigamy and strategic naturalization.

Border-crossing migration has led to new geographies of social and economic inequality. Brokers emerge in the border areas who are taking benefit from the very precarious status of illegal migrants. Sather (1997) and Horstmann (2001) describe how brokers in Sabah and Langkawi are recruiting kin from neighbouring Sulu and southern Thailand and establish relationships of bounded labour. In these exploitative relations, the refugees or illegal immigrants are expected to provide unpaid labour to their patrons or to pay them in kind. This broker and the figuration is intrinsic to the borderland. The example shows how much state borders affect the lives of ethnic minorities. It also shows that the function of kinship relations has changed. In fact, the cultures of relatedness may have been fundamentally altered by borders. In the context of exploitative relations, kin can be invented and documents can be falsified. The illegal migrants from southern Thailand or the Sulu Sea may claim traditional obligations of kin to help, but the fact that old migrants with citizenship status are distinguishing themselves from the new migrants without any citizenship rights show that there are limits to moral claims.

This negotiation between the established and the outsiders, between citizen and immigrants in border provinces highlights border-crossing and migration which is rapidly changing the 
landscapes of Southeast Asia, with Thailand and Malaysia emerging as the main receiving migrant countries. In an age of rapid intensification of border-crossing movement, migration emerges as one of the major forces of social transformation, posing fundamental questions on the boundedness of nations and the inevitable dilemma of citizenship, differentiating in different categories of peoples- citizen and non-citizens.

Borderland scholars are interested in the relationships of established and the immigrants, in the networks of ethnic minorities which are trapped in different nations, but are reviving their cultural ties, and in the everyday life management of diversity in the border provinces and towns. In short, we study the ways in which new borders are set up, in which the growing flow of people and the trafficking of human flesh is regulated, and the ways in which immigrants cope with the legal and material realities of the recipient countries. Horstmann (2002) and Wadley (2000b) are writing about transnational circular labour migration and transnational migrant circuits. In Ban Sarai, the Satun Malay in Thailand are going to fish illegally in Langkawi, Malaysia, with every household having members working in Langkawi and Satun Muslim women are increasingly being married to Langkawi Malaysian husbands. Illegal men are subject to arrest and women are subject to unequal gender relationships. In West Kalimantan, Iban spend most of their time in West Malaysia and Brunei to work as cheap labour.

Unlike long-distance migrants, such as Bosnian and Nigerian Muslims, they mingle easily into local society, assimilating to local culture and language and relying on kin relations on the other side of the border. The Satun Malays and the Iban are attracted by currency disparities and higher wages. In this way, the socio-economic differences give stimulus to circular labour migration, while moral and kin obligations, and status politics, motivate the returning to home. Due to the huge economic differences between nations, people move across the border to benefit from the growing demand of cheap labour in the factories, construction and fisheries of Thailand, Malaysia, Brunei and Singapore. Although coming from the same roots, former Indonesian immigrants who have become fully Malay are now distinguishing themselves from the Indonesian newcomers (Miyazaki 2000b).

On the Thai-Burmese border, forced migration is leading to the most severe forms of exploitation on the side of labourers from Burma. Burmese migrant workers are vulnerable to physical and sexual abuse (Pim Koetsawang 2001). The state is trying to regulate the flow of peoples and commodities across the border, issuing border passes, establishing fines, arresting migrants, and confining movement in refugee camps. Yet, the state is consisting of multiple, conflicting agencies. Borderland scholars are interested in the relations of power on a local level. On the Thai-Burmese border, the National Security Council, the Ministry of Labour and Social Welfare, the Immigration Bureau, and the Royal Thai Police are all involved in the regulation and surveillance of illegal migrant workers. The documentation of human flow and trafficking across the Thai-Burmese border in government offices is bleak. The 2,400 km long border between Thailand and Myanmar is stretching from the Golden Triangle in the north to Kawthaung in the south and is generally very porous and not rigidly monitored by either country (Supang Chantavanich et al 2000). With Thailand having had millions of migrants over the past decade, trafficking of women and children is a huge business for well established networks. In Ranong province alone, over 100000 Burmese are working in fishing and fish-related industries, constituting long-term Burmese immigrant communities. Supang Chantavanich point outs on 
the basis of careful research that cross-border sex workers and fishery labourers are particularly vulnerable to HIV/AIDS infection.

Related, scholars of borderlands are keen to explore the totality of the life worlds of migrant workers in long-term ethnographic studies in order to catch the diversity of everyday relations in, say, a border town. ${ }^{7}$ While some of the ethnographic material may be used to the disadvantage of migrant workers, borderland scholars are qualified to help in the organization and articulation of vulnerable migrants.

\section{Transnationalism, Moral Communities and Globalisation}

The activities of cross-river boat operators, long-distance truck operators and women involved in long-distance trade show that members of frontier communities can be active participants in the creation and maintenance of borders and that traders are eager to benefit from the resources which borders create (Walker 1999). By exploring the networks of small-scale trading women, Walker unravels the myth of the subsistence economy in Laos, questions marginality and emphasises the role of women in long-distance cross-border trade. Adopting a regulatory concept of border-crossing trade, Walker uses a dynamic concept in order to show the role of trading networks and routes in historical times as well as in the present. Walker argues that his ethnographic study on the interaction of small-scale traders with customs and immigrant officials show that people and connections are differentially located into relations of power. Far from fading away, borderlands get a new centrality in globalisation and offers opportunities for some and constraints for others. The role of the trading women in the transformation of a post-socialist economy can not be overestimated: It is them who supply the population with the bulk of commodities and the newest information (see Tagliacozzo 1999) for a historical study).

The intensification of border-crossing practice and movement involves well-established kinship, trading, cultural and religious networks. The invention of borders and their closure are responsible for the marginalization of ethnic minorities in the space of the nation-state. Ethnic and religious minorities have been subjected to the brutality of state terror and sometimes genocide. In Sipsongpanna, Buddhist monks are the key cultural agents in the revival of precolonial moral communities in China, Burma, Thailand and Laos (Davis 2002, Evans/Hutton/Eng 2000). ${ }^{8}>$ From the 1950s until the 1970s, century-old temples have been destroyed, Buddhist images were publicly burned, Thai monks were forced to unfrock and Thai elites have been sent to re-education camps. This suppression of ethnic and religious identity has forced Buddhist activities underground and has created a shared oppressed identity. In Burma, too, the Tai alphabet was banned and local religion repressed. Davis (2002) describes the joy and enchantment of post-modern reconstructions of Buddhist and ethnic identity in Sipsongpanna: Border-crossing moral communities are maintained through a large network of minority temples, which function as schools, sub-radar political centres, and inns for travelling monks. This horizontal temple network is hold together by the networks of mobile intellectuals and by the flows of audio- and videotapes across the border. Davis argues that post-modern flows of people and commodities are building on pre-modern concepts of political and religious organization in Sipsongpanna. Globalization is criss-crossing political boundaries and re-introducing ethnic consciousness, the Thai alphabet and Budhhist education to the Thai Lue of Sipsongpanna. Through the networks of monks, traders and artisans, Buddhist scriptures have been developed, musical instruments exchanged and mural painting in temples taught. 
Globalization in many ways facilitates the revival of religious and ethnic identity in Southeast Asia and puts the borderlands in a new spotlight. The flow of people, commodities and ideas is not arbitrary, but is based on historical ethnic and religious ties in local spaces. Especially ethnic minorities who are trapped in marginal spaces of the nation-state are using the new spaces to reconstruct transnational ethnic and religious communities.

Tapp (2001) reports that since the 1980s there have been growing return visits of nostalgiadriven Hmong to Thailand and Laos where they hoped to find sources of cultural heritage and ancestral homelands. ${ }^{9}$ He shows that the remittances and folkloric projections of returning Hmong diaspora are changing the culture of local action. The quest for authenticity has led the dispersed Hmong-Diaspora to use the space of the Internet to reinvent Hmong identity and to forge new global community links. Tapp describes how Hmong migrants return to Hmong refugee camps on the Thai-Lao border at the Hmong New Year in search of their roots. In the refugee process, whole families were divided. Reunions of family members in Lao villages are joyous, emotional and lead to the regular sending of remittances back to families in Laos. Remittances and images of the Hmong in the US are reshaping the local economy and culture. Thus, the studies on the Thai Lue and the Hmong show that the new space of communication, travel and encounter is used to reconstruct long-distance nationalism (Anderson 1998).

\section{Common Agendas}

In a time, in which nationalism and national identity come under great pressure through transnational communities, borderlands in Southeast Asia are a laboratory of social and cultural change. This review article has sorted out some common agendas of scattered studies. In order to advance in the recent field, we need to centre the margin and to connect local studies to border studies in Africa, in Latin America, in Europe, and the US-Mexican border.

Clearly, borderland studies of Southeast Asia at this stage are lacking in comparative depth. As Hall recalls, while every borderland has its unique manifestations, there are systemic processes. We propose that these systemic processes can best be studied in a framework which gives due agency to borderland communities and to their agency. The main question is how ethnic minorities are giving meaning and shape to marginal local space. What quickly emerges from borderland studies in Southeast Asia are the multiple and decentered ties of ethnic minorities which have been incorporated into the space of the nation-state.

The Thai Lue Buddhist networks in mainland Southeast Asia, the Muslim networks in mainland and insular Southeast Asia or the vast maritime spaces from the Sulu Sea to the Mergui archipelago inhabited by the Sama-Bajau and the Moken illustrate indigenous cultures on whom the borders and hegemonic scripts of the colonial and post-colonial state have been imposed and who were forced to drastically change their modes of living. In addition, the Thai-Burmese border and the Malaysian-Indonesian border show that migrants are making all efforts to cross the porous border in order to flee from human rights abuses, from the destruction of natural resources, and from poverty. Transnational migrant circuits on the border and the multiple networks of ethnic and religious networks across borders are questioning the exclusive nature of the nation-state, its management of culture and people, and the exclusive character of state concepts. Citizenship guarantees and protects the rights of a few, while citizenship increasingly becomes an instrument of control which is producing different categories of people and which is increasingly distinguishing between citizen and non-citizen. 
Fieldwork in Southeast Asia shows that scholars can not reduce the analysis to the state border and its surroundings, as migrants, refugees, and tourists are not restricted to local space, but have a sometimes low-profile and marginal- presence and existence in the metropolis or the centre. One of the major conclusions of this survey is that scholars of borderlands should concentrate on the cultural complexity of the borderland communities themselves and on their transnational networks and spaces and not on the invented entities of the nation-states. In a framework of world-society, scholars of borderlands are centring on the margin by documenting the life worlds and cosmologies of indigenous people, languages and culture which transcend national borders. The current revival of old ties and the globalization of ethnic and religious codes is a particular promising field for borderland scholars. There is a shift of emphasis- after sovereignty of the nation-state- on the concrete interaction of minorities and the state on the ground and on the local re-workings and filters of national and global scripts in local contexts. The ethnography of this interface seems crucial to the social transformation of Southeast Asia. The intensification of transnational, border-crossing life challenges much of our intellectual baggage of static concepts. Identities are not only multifaceted, but they can change and the fluidity and ambiguity of identities- Thai and Malay, Malay and Indonesian etc.-is a central character of borderlands.

Writing from the interstices (Thongchai Winichakul 2002), border studies of state building, globalisation and resistance in local spaces take a perspective of longue durée as territorial boundaries, passports and visa are a relatively new phenomenon. The imagined communities of the post-colonial state are not promise, but danger and often nightmare for indigenous people of Southeast Asia who fall under the programmes of development and civilisation of the postcolonial state. There is no doubt that the bordering of Southeast Asia has affected the lives of border people to a grand scale. But while the state border has been set up by the nation-state as a marker of statehood, basic state concepts, such as sovereignty and citizenship, exist rather on paper than in reality. Far from the national centre, the control of the state on the transformation of borderlands is limited. Many scholars of borders have shown that local people constantly defy the efforts of the state to control them. Border communities play a very significant role in the making and in the transformation of identity by negotiating the highly ambiguous space of the frontier. In marginal spaces, where one nation-state ends and another history begin, local communities are playing with identity or are making use of the border.

Questions of post-colonialism have challenged the power and meaning of boundaries as they relate to our understanding of insiders and outsiders. With social life being typically storied, the construction of identity narrative is itself political action and is part of the distribution of social power in society. Newman and Paasi note that boundaries are part of the discursive landscape of social power, control and governance, which extends itself into the whole society and which is produced and reproduced in various social and cultural practices (Newman and Paasi 1998).

In the study of state boundaries, it is important to know whose plots or turfs dominate these identity narratives, what is excluded or included by them and how the representations of us and them are produced and reproduced in various social practices, such as media, education, etc.

The approach of Newman and Paasi has been adopted to show that the border is not a fixed entity, but is always constructed on various levels of social orders and historically contested. But the marginal history project of Thongchai and van Schendel has been presented here to accept the challenge of exploring the ways in which borders between ethnic groups- majorities and minorities- are dissolved or enhanced. One of the central interests of borderland scholars concerns 
the ethnography of border-crossing local agency and the ways in which this agency influences the dissolution of borders or their reinforcement as a basic structure of state formation and globalization. While every borderland has to be studied in its own right, the question of just how border people are ticking in history is an approach which will be viable for all borderlands.

\section{References:}

Anderson, Benedict (1983): Imagined Communities: Reflections on the Origin and Spread of Nationalism. London: Verso.

Anderson, Benedict (1998): The Spectre of Comparisons. Nationalism, Southeast Asia and the World. London/New York: Verso

Baud, Michiel and Willem van Schendel (1997): Towards a Comparative History of Borderlands, Journal of World History, Vol. 8, No. 2, pp. 211-242.

Benjamin, Geoffrey (1988): The Unseen Presence. A Theory of the Nation-State and its Mystifications. Singapore: Dept. of Sociology, National University of Singapore.

Bryant, Raymond (1997): The Political Ecology of Forestry in Burma, 1824-1994. London: Hurst.

Carsten, Janet (1998): Borders, Boundaries, Tradition and State on the Malaysian Periphery. In: Hastings Donnan and Thomas M. Wilson (eds.): Border Identities. Nation and State at International Frontiers. Cambridge: Cambridge University Press.

Chantavanich, Supang/Allen Bessey/Shakti Paul (2000): Mobility and HIV/AIDS in the Greater Mekong Subregion, Report of the Asian Research Center of Migration for the Asian Development Bank.

Cheah Boon Kheng (1988): The Peasant Robbers of Kedah 1900-1929. Historical and Folk Perceptions. Singapore: Oxford University Press.

Davis, Sara (2002): Premodern Flows in Postmodern China: Globalization and the Sipsongpanna Tai Lue. Unpublished Manuscript.

Donnan, Hastings and Thomas M. Wilson (2000): Borders: Frontiers of Identity, Nation and State. Oxford and New York.

Donnan, Hastings and Thomas M. Wilson (eds) (1998): Border Identities. Nation and State at International Frontiers. Cambridge: Cambridge University Press.

Evans, Grant, Christopher Hutton and Kuah Khun Eng (eds) (2000): Where China meets Southeast Asia. Social and Cultural Change in the Border Regions. Singapore: Institute of Southeast Asian Studies.

Falla, Jonathan (1991): True Love and Bartholomew. Rebels on the Burmese border. Cambridge: Cambridge University Press.

Hall, Thomas D. (2000): Frontiers, Ethnogenesis, and World-Systems: Rethinking the Theories. In Hall (ed): A World-Systems Reader. New Perspectives on Gender, Urbanism, Cultures, Indigenous People, and Ecology. Lanham et al: Rowman \& Littlefield Publishers.

Herzfeld, Michael (1997): Cultural Intimacy. Social Poetics in the Nation-State. New York/London: Routledge. 
Horstmann, Alexander (2001): Trapped Ethnic Minorities and the Local Reworking of Citizenship at the Thailand-Malaysian Border. Lecture presented to the Centre of Southeast Asian Studies (CSEAS), Kyoto University, 12. November 2001.

Horstmann, Alexander (2002): Rethinking Citizenship in Thailand. Identities at the Fringe of the Nation-state in National and Post-National Times. Paper presented to the 8th International Conference of Thai Studies, 09.-12.01.2002, Nakhon Phanom, Thailand.

Horstmann, Alexander (forthcoming): Imagined Moral Communities, Transnationalism and the Ambiguity of National Intimacy. Paper Presented to the First Inter-Dialogue Conference on Southern Thailand: Experiencing Southern Thailand: Current Transformations from a People $s$ Perspective, 13-15 June 2002, Pattani, Thailand, hosted by Prince of Songkla University and Harvard University.

Ishikawa, Noburu (2001): Genesis of Nation Space: a Case from the Borderland of Southwestern Sawarak, 1871-1941. Paper presented to the Conference Globalization and Local Culture: A Dialectic toward New Indonesia, organised by the Indonesian Journal of Anthropology, Padang, July 18-21 2001.

Koetsawang, Pim (2001): In search of Sunlight. Burmese Migrant Workers in Thailand. Bangkok: Orchid Press.

Miyazaki, Koji (2000a): Javanese-Malay: Between Adaptation and Alienation. In: Sojourn, Vol. 15, No. 1, pp. 76-99.

Miyazaki (2000b): Culture Moves: Contemporary Migration in Southeast Asia. In: Abe Kenichi/ Ishii Masako: Population movement in Southeast Asia: Changing Identities and Strategies for Survival, JCAS Symposium Series No. 10, National Museum of Ethnology, Osaka.

Miyazaki, Koji (ed) (2001): Socio-cultural Processes of Development: Sabah and BIMPEAGA. Final Report of Research Project. Socio-cultural Processes of Development in Sabah. ILCAA: Tokyo: Tokyo University of Foreign Studies.

Newman, David and Anssi Paasi (1998): Fences and Neighbours in the Postmodern World: Boundary Narratives in Political Geography. Progress in Human Geography Vol. 22, No. 2 (1998), pp. 186-207.

Nugent, Paul and A. I. Asiwaju (eds) (1996): African Boundaries. Barriers, Conduits and Opportunities. London/New York: Pinter.

Pries, Ludger (2000): Transnational Social Space: Do We Need a New Approach in Response to New Phenomena? In: Ludger Pries (ed): New Transnational Social Spaces. International Migration and Transnational Companies. London. Routledge.

Rajah, Ananda (1990): Ethnicity, Nationalism, and the Nation-State: The Karen in Burma and Thailand. In: Gehan Wijeyewardene (ed): Ethnic Groups across National Boundaries in Mainland Southeast Asia. Singapore: Institute of Southeast Asian Studies.

Sather, Clifford (1997): The Bajau Laut: Adaptation, History and Fate in a Maritime Fishing Society of South-eastern Sabah. Oxford: Oxford University Press.

Shapiro, Michael J. and Hayward R. Alker (1996): Challenging Boundaries. Global Flows, Territorial Identities. Borderlines, Vol. 2, Minneapolis, London: University of Minnesota Press. 
Tagliacozzo, Eric (1999): Secret Trades of the Straits: Smuggling and State-Formation along a Southeast Asian Frontier, 1870-1910, PhD dissertation, History Department, Yale University (UMI).

Tapp, Nicholas (1989): Sovereignty and Rebellion: The White Hmong of Southern Thailand. Singapore: Oxford University Press.

Tapp, Nicholas (2000): A New Stage in Thai Regional Studies: The Challenge of Local Histories. In: Andrew Turton (ed): Civility and Savagery. Social Identity in Tai States. Richmond, Surrey: Curzon.

Tapp, Nicholas (2001): Diasporic Returns: The Sociology of a Globalised Rapprochement. Unpublished Manuscript.

Turner, Frederick Jackson (1920/1996): The Frontier in American History. New York: Dover

Wadley, Reed (2000a): Warfare, pacification, and environment: Population dynamics in the West Borneo borderlands (1823-1934). Moussons: Social Science Research on Southeast Asia 1, pp. 41-66.

Wadley, Reed (2000b): Transnational Circular Labour Migration in Northwestern Borneo. In: Husson L./Charbit Y. (eds): Migratory Dynamics in Eastern Asia, Vol. 16, No. 1, pp. 127149.

Wadley, Reed (2001): Trouble on the Frontier: Dutch-Brooke relations and Iban rebellion in the West Borneo borderlands (1841-1886), Modern Asian Studies Vol.35, Nr. 3: 623-644.

Wadley, Reed (2002): Punitive Expeditions and Divine Revenge: Oral and Colonial Histories of Rebellion and Pacification in Western Borneo, 1886-1902. Unpublished Manuscript.

Walker, Andrew (1997): The Legend of the Golden Boat: Regulation, Transport and Trade in North-Western Laos. Ph.D. thesis. Canberra: Australian National University.

Wijeyewardene, Gehan (1989): Majorities, Minorities and National Boundaries, ThaiYunnan Project Newsletter 4, pp. 1-2.

Winichakul, Thongchai (1994): Siam Mapped. A History of the Geo-body of a Nation. Honolulu: University of Hawaii Press.

Winichakul, Thongchai (2000): The Others Within: Travel and Ethno-Spatial Differentiation of Siamese Subjects 1885-1910. In Andrew Turton (ed): Civility and Savagery. Social Identity in Tai States. Richmond, Surrey: Curzon.

Winichakul, Thongchai (2002): Writing at the Interstices: Southeast Asian Historians and Post-National Histories in Southeast Asia, paper presented to the panel on Boundary Margin and Local Autonomy in Thai History, 8th International Conference on Thai Studies, Nakhon Phanom, Ramkamhaeng University, January 09.-12, 2002.

\section{Endnotes}

\footnotetext{
${ }^{1}$ Dr. Alexander Horstmann is a visiting associate professor at the Institute of Languages and Cultures of Asia and Africa (ILCAA), Tokyo University of Foreign Studies. The author acknowledges the generous support and the
} 
huge hospitality given by Dr. Ryoko Nishii and Prof. Dr. Koji Miyazaki. I would like to thank Dr. Riwanto Tirtusudarmo for sharing his research interest on the Indonesian/Malaysian border during his stay at ILCAA. Special thanks are due to the numerous authors who have answered my call for collaboration on this review paper in the $\mathrm{H}$ Southeast Asia list, organized by Prof. Paul H. Kratoska (National University of Singapore).

2 This review essay draws on conference panels on borderland studies in Southeast Asia, including panels organized by Ananda Rajah and Carl Grundy Warr (Singapore), Riwanto Tirtosudarmo (Jakarta), Alexander Horstmann and Ryoko Nishii (Tokyo), Riwanto Tirtusudarmo, Reed Wadley (Arizona) and Noboru Ishikawa (Kyoto), and by Sara Davis (Los Angeles).

${ }^{3}$ Rajah (1990) suggests that the notions of ethnicity and nation-state are not quite as simple as they are often made out to be. Indeed, we argue that the anthropology of borderlands in Southeast Asia can be used to re-examine some of our key vocabulary in social sciences. Rajah asks for a shift of perspective which is looking for the complex relations between ethnicity and nation-state.

${ }^{4}$ The antidote to the approach developed here is provided by the cultural imperialism of Frederick Jackson Turner (1861-1932) who regarded the American frontier as the zone of most rapid and effective Americanization. For a discursive narrative of the border The Frontier in American History is a worth reading (Turner 1920/1996).

${ }^{5}$ The following discussion relies heavily on Bryant (1997). Bryant s study is one of the rare full monographs in borderland studies in Southeast Asia.

${ }^{6}$ For a detailed account of the Karen Rebels on the Burmese border, see Jonathan Falla (1991): True Love and Bartholomew. Rebels on the Burmese Border. Cambridge: Cambridge University Press.

${ }^{7}$ For a detailed account on the role of immigrants in the making of Sabah, see the final report of the research project Socio-cultural Processes of Sabah . Miyazaki, K. (ed) (2001): Socio-Cultural Processes of Development: Sabah and BIMP-EAGA. Institute for the languages and Cultures of Asia and Africa (ILCAA), Tokyo University of Foreign Studies.

${ }^{8}$ The reader Where China meets Southeast Asia (Evans/Hutton/Eng 2000) is also interesting for the shift of perspective for many contributors who did not pay much attention to the border in their previous work. The reader is the most important interdisciplinary effort in studying the transformation of the Chinese borderlands with Indochina in the post-socialist age.

9 This work is part of a larger research project of Nicholas Tapp on Communal Voluntary Diasporic Public Culture for which fieldwork is undertaken in Australia and Taiwan, China, Indochina and Thailand. 